\title{
Front Matter: Volume 10632
}

, "Front Matter: Volume 10632," Proc. SPIE 10632, Anomaly Detection and Imaging with X-Rays (ADIX) III, 1063201 (5 July 2018); doi:

$10.1117 / 12.2500496$

SPIE. Event: SPIE Defense + Security, 2018, Orlando, FL, United States 


\title{
Anomaly Defection and Imaging with X-Rays (ADIX) III
}

\author{
Amit Ashok \\ Joel A. Greenberg \\ Michael E. Gehm \\ Mark A. Neifeld \\ Editors
}

17-18 April 2018

Orlando, Florida, United States

Sponsored and Published by

SPIE 
The papers in this volume were part of the technical conference cited on the cover and title page. Papers were selected and subject to review by the editors and conference program committee. Some conference presentations may not be available for publication. Additional papers and presentation recordings may be available online in the SPIE Digital Library at SPIEDigitalLibrary.org.

The papers reflect the work and thoughts of the authors and are published herein as submitted. The publisher is not responsible for the validity of the information or for any outcomes resulting from reliance thereon.

Please use the following format to cite material from these proceedings:

Author(s), "Title of Paper," in Anomaly Detection and Imaging with X-Rays (ADIX) III, edited by Amit Ashok, Joel A. Greenberg, Michael E. Gehm, Mark A. Neifeld, Proceedings of SPIE Vol. 10632 (SPIE, Bellingham, WA, 2018) Seven-digit Article CID Number.

ISSN: 0277-786X

ISSN: 1996-756X (electronic)

ISBN: 9781510617759

ISBN: 9781510617766 (electronic)

Published by

SPIE

P.O. Box 10, Bellingham, Washington 98227-0010 USA

Telephone +1 3606763290 (Pacific Time) · Fax +1 3606471445

SPIE.org

Copyright (c) 2018, Society of Photo-Optical Instrumentation Engineers.

Copying of material in this book for internal or personal use, or for the internal or personal use of specific clients, beyond the fair use provisions granted by the U.S. Copyright Law is authorized by SPIE subject to payment of copying fees. The Transactional Reporting Service base fee for this volume is $\$ 18.00$ per article (or portion thereof), which should be paid directly to the Copyright Clearance Center (CCC), 222 Rosewood Drive, Danvers, MA 01923. Payment may also be made electronically through CCC Online at copyright.com. Other copying for republication, resale, advertising or promotion, or any form of systematic or multiple reproduction of any material in this book is prohibited except with permission in writing from the publisher. The CCC fee code is 0277 $786 \mathrm{X} / 18 / \$ 18.00$.

Printed in the United States of America.

Publication of record for individual papers is online in the SPIE Digital Library.

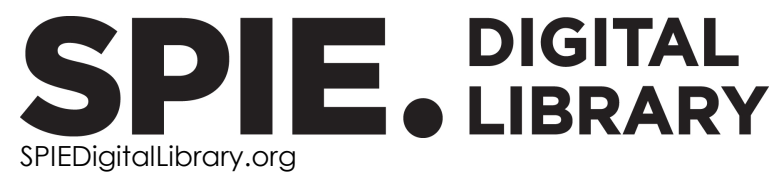

Paper Numbering: Proceedings of SPIE follow an e-First publication model. A unique citation identifier (CID) number is assigned to each article at the time of publication. Utilization of CIDs allows articles to be fully citable as soon as they are published online, and connects the same identifier to all online and print versions of the publication. SPIE uses a seven-digit CID article numbering system structured as follows:

- The first five digits correspond to the SPIE volume number.

- The last two digits indicate publication order within the volume using a Base 36 numbering system employing both numerals and letters. These two-number sets start with $00,01,02,03,04$, 05, 06, 07, 08, 09, OA, OB ... 0Z, followed by 10-1Z, 20-2Z, etc. The CID Number appears on each page of the manuscript. 


\title{
Contents
}

\author{
$\checkmark \quad$ Authors \\ vii Conference Committee
}

DEEP LEARNING TECHNIQUES IN X-RAY SCREENING

1063203 Automatic threat recognition of prohibited items at aviation checkpoint with x-ray imaging: a deep learning approach (Invited Paper) [10632-2]

1063204 Deep learning based sparse view x-ray CT reconstruction for checked baggage screening [10632-3]

1063205 Application of machine learning to x-ray diffraction-based classification [10632-4]

\section{SCATTER-BASED IMAGING AND DETECTION I}

1063209 Towards an $\mathrm{x}$-ray-based coded aperture diffraction system for bulk material identification (Invited Paper) [10632-8]

SCATTER-BASED IMAGING AND DETECTION II

$10632 \mathrm{OB}$ The role of texturing in x-ray diffraction tomography [10632-10]

\section{SYSTEMS ANALYSIS AND ALGORITHMS}

10632 OD Joint reconstruction and material classification in spectral CT (Invited Paper) [10632-12]

$10632 \mathrm{OE}$ Consensus relaxation on materials of interest for adaptive ATR in CT images of baggage (Invited Paper) [10632-13]

$10632 \mathrm{OF}$ An information theoretic approach to system optimization accounting for material variability [10632-14] 
Proc. of SPIE Vol. 10632 1063201-4

Downloaded From: https://www.spiedigitallibrary.org/conference-proceedings-of-spie on 26 Apr 2023 Terms of Use: https://www.spiedigitallibrary.org/terms-of-use 


\section{Authors}

Numbers in the index correspond to the last two digits of the seven-digit citation identifier (CID) article numbering system used in Proceedings of SPIE. The first five digits reflect the volume number. Base 36 numbering is employed for the last two digits and indicates the order of articles within the volume. Numbers start with 00, 01, 02, 03, 04, 05, 06, 07, 08, 09, OA, OB...0Z, followed by 10-12, 20-2Z, etc.

Ashok, Amit, 04, OF

Babaheidarian, Parisa, OD

Bilgin, Ali, 04

Carin, Lawrence, 03

Carlson, David, 03

Castañón, David A., OD

Chandrasekaran, Hema, OE

Coccarelli, David, OF

Diallo, Souleymane O., 03, 09

Gehm, Michael, OF

Greenberg, Joel A., 05, 09, OB, OF

Gregory, Christopher, 03, 09

Hazineh, Dean, OB

Heilmann, Geert, 03

Keohane, Brian, OB

Liang, Kevin J., 03

MacGibbon, Chris, OB

Mandava, Sagar, 04

Martz, Harry E., OE

Masoudi, Ahmad, OF

Paglieroni, David W., OE

Pechard, Christian, OE

Roe, Kris, 03, 09

Sigman, John B., 03

Spell, Gregory P., 03

Tadlock, K., 09

Thamvichai, Ratchaneekorn, OF

Voris, Jay, OF

Wolter, Scott, 05, 09, OB

Zhao, Bi, 05 
Proc. of SPIE Vol. 10632 1063201-6

Downloaded From: https://www.spiedigitallibrary.org/conference-proceedings-of-spie on 26 Apr 2023 Terms of Use: https://www.spiedigitallibrary.org/terms-of-use 


\section{Conference Committee}

Symposium Chair

Arthur A. Morrish, Raytheon Space and Airborne Systems

(United States)

Symposium Co-chair

Ruth L. Moser, Air Force Research Laboratory (United States)

Conference Chairs

Amit Ashok, College of Optical Sciences, The University of Arizona (United States)

Joel A. Greenberg, Duke University (United States)

Michael E. Gehm, Duke University (United States)

Mark A. Neifeld, The University of Arizona (United States)

\section{Conference Program Committee}

Mark A. Anastasio, Washington University in St. Lovis (United States)

Ali Bilgin, The University of Arizona (United States)

Ali Can, GE Global Research (United States)

Eric W. Clarkson, The University of Arizona (United States)

Mini Das, University of Houston (United States)

Edward D. Franco, Rapiscan Systems Inc. (United States)

Christopher W. Gregory, Smiths Detection Inc. (United States)

Tim E. Harvey, EMF Corporation (United States)

Kris Iniewski, Redlen Technologies (Canada)

Harry E. Martz, Lawrence Livermore National Laboratory (United States)

Joseph A. O'Sullivan, Washington University in St. Louis (United States)

Sean Pang, CREOL, The College of Optics and Photonics, University of Central Florida (United States)

Lei Tian, University of California, Berkeley (United States)

Laura Waller, University of California, Berkeley (United States)

Sharene Young, U.S. Department of Homeland Security

(United States) 
Proc. of SPIE Vol. 10632 1063201-8

Downloaded From: https://www.spiedigitallibrary.org/conference-proceedings-of-spie on 26 Apr 2023 Terms of Use: https://www.spiedigitallibrary.org/terms-of-use 